Project Summary of \# 86729

\title{
Mechanisms of $\mathrm{CCl}_{4}$ Retention and Slow Release in Model Porous Solids and Sediments
}

Lead PI: $\quad$ Robert Riley - Pacific Northwest National Laboratory

Co-PI: $\quad$ James Amonette - Pacific Northwest National Laboratory

Co-PI: $\quad$ Brent Peyton - Washington State University

Annual Report submitted on the PNNL portion of EMSP Project \# 86729

\section{Research Objective:}

A migration-resistant fraction (MRF) is a portion of a polluted sediment's contaminant inventory that exhibits slow release. Slow release is a key process that controls organic contaminant transport and fate in a plume long after the major portion of the contaminant inventory of a source term has been depleted or removed. Slow release rates are not well understood nor are they commonly accounted for in subsurface numerical transport models. In this project, we propose to study the accumulation and slow-release behavior of carbon tetrachloride $\left(\mathrm{CCl}_{4}\right) \mathrm{MRF}$ as a function of time, contaminant concentration and different physicochemical properties of sediments. Both model materials that mimic the physical/chemical properties of sediments and natural sediments will be used in project studies. Experiments will be conducted at macro- and microscopic scales under both unsaturated (Washington State University-WSU) and saturated conditions (Pacific Northwest National Laboratory-PNNL). The results will be used to 1) develop a mechanistic description of slow release of $\mathrm{CCl}_{4}$ in the subsurface environment and 2) lay the groundwork for improving the robustness of numerical models that predict organic contaminant transport and fate under natural conditions. The outcomes of this study are expected to improve the conceptual model of $\mathrm{CCl}_{4}$ subsurface transport and fate at different physical scales and have an impact on remediation and site closure decision-making at Department of Energy (DOE) sites, especially in situations involving the potential application of natural attenuation. This report summarizes work performed on the PNNL component of the project after the first 8 months of a three-year project. Progress on the WSU component of the project is addressed under a separate annual report submission.

\section{Research Progress:}

Critical to the success of this project is access to sediments of varying physical/chemical properties that can be used in laboratory experiments to study the retention and slow release of carbon tetrachloride at different spatial scales. It is preferable to obtain samples from DOE sites, particularly those with known carbon tetrachloride contamination. To meet this need, collaboration has occurred between several DOE facilities. Sediments for use in this project were obtained in December 2002 during the drilling of a bore hole in Hanford's 200 West area that was intended to intercept the underlying unconfined aquifer in an area where the groundwater was known to be contaminated with carbon tetrachloride at a level of approximately 2 parts per million. The well was to support the CERCLA RI/FS process for reaching decisions for the remediation of carbon tetrachloride in the Hanford site's 200 West Area. Sediment was removed from the borehole using air injected under high pressure (air lift mode) that eliminated the potential for sediment contamination afforded by other methods. Five-kilogram quantities of sediment were collected from the Hanford formation ( 80 to $85 \mathrm{ft}$ depth below ground surface), the Ringold formation (150 to $155 \mathrm{ft}$ depth) and in the Ringold formation at a location above the 
water table at a depth of 197 to $222 \mathrm{ft}$. and a sediment sample within the aquifer at a depth of 245 ft.

Through the Idaho National Engineering and Environmental Laboratory's (INEEL's) Lithologic Core Library, samples of sediments have been obtained from two interbeds underlying INEEL's Subsurface Disposal Area (SDA) of the Radioactive Waste Management Complex. In the past, the SDA received carbon tetrachloride-containing wastes from DOE Rocky Flats facility. The sediments are anticipated to contain moderate to high levels of clay content. These sediments complement the physical properties of Hanford sediments that tend to be more gravelly/sand in nature. Also acquired was a sample of sediment known to be associated with DOE's Savannah River site trichloroethylene plume.

Table 1 summarizes organic carbon content and surface area measurements for collected sediments. Organic carbon content for all sediments was low $(<0.1 \%)$ with surface areas varying by up to a factor of 50. The low organic carbon content of the sediments suggests that the nature of the meso- microporous structures of the sediments will make a greater than normal contribution in influencing the slow release behavior of any MRF detected in experiments using these sediments relative to sediments containing higher organic carbon contents.

Table 1. Initial Results of Characterization of Sediments

\begin{tabular}{|l|c|c|c|}
\hline \multicolumn{1}{|c|}{ Sediment Source } & Formation and Depth (ft) & $\begin{array}{c}\text { Organic } \\
\text { Carbon } \\
\text { Content }(\%)\end{array}$ & $\begin{array}{c}\text { Surface Area } \\
\left(\mathrm{m}^{2} / \mathrm{g}\right)\end{array}$ \\
\hline $\begin{array}{l}\text { Hanford Borehole 299-W15- } \\
43\end{array}$ & Hanford (80-85) & 0.09 & 6.5 \\
\hline $\begin{array}{l}\text { Hanford Borehole 299-W15- } \\
43 \text { (duplicate analy sis) }\end{array}$ & Hanford (80-85) & 0.04 & 5.6 \\
\hline & Ringold (150-155) & 0.04 & 15.0 \\
\hline & Ringold (197-222) & 0.04 & 7.9 \\
\hline & Ringold (245) & 0.05 & 10.6 \\
\hline $\begin{array}{l}\text { INEEL Subsurface Disposal } \\
\text { Area }\end{array}$ & Interbed (103-107) & 0.06 & 26.4 \\
\hline & Interbed (226-241) & 0.09 & 64.5 \\
\hline Savannah River & Tobacco Road Sand & 0.01 & 1.3 \\
\hline
\end{tabular}

\section{Planned Activities:}

Characterization of the physical and chemical properties of the sediments collected to date will be completed. Additional analyses to be performed include particle size and pore size distributions, cation exchange capacity, mineralogy, and textural analysis.

Arrangements have been made in collaboration with Fluor Daniel Hanford, Inc. for acquisition of sediments from a slant borehole to be drilled under the 216 Z-9 trench at DOE's Hanford site. The 216 Z-9 was the major recipient of carbon tetrachloride waste disposed to the ground in Hanford's 200 West area. Carbon tetrachloride was co-disposed with significant quantities of organic contaminants (i.e., lard oil and alkylphosphates). It is anticipated that sediments collected from under the trench may have significantly different physical chemical properties (e.g., higher organic carbon content) than those that have been collected from other locations on the Hanford site and at other DOE sites (i.e., those described in Table 1 above) and different $\mathrm{CCl}_{4} \mathrm{MRF}$ 
magnitude and slow release behavior. Collected samples will be characterized as described above for the other samples.

Samples of characterized sediments will be provided to our university collaborator (Brent Peyton at WSU) to support studies of carbon tetrachloride resistant fractions in unsaturated sediments.

Selected model materials (i.e., pillared clays) will be synthesized and subjected to characterization using X-ray scattering, optical, and transmission electron microscopy techniques to determine meso- and microporosity characteristics.

Experiments will be performed to compare the behavior of carbon tetrachloride and fluorotribromomethane in selected model materials and sediments under saturated conditions.

Experiments (kinetic and steady-state) to determine the behavior of fluorotribromomethane in selected model materials at the meso/microscale (i.e., the rate of filling and emptying of meso/micropores and the competitive effects of water) will be initiated (Jim Amonette, PNNL Co-PI). This assumes demonstration of comparable behavior between carbon tetrachloride and fluorotribromomethane on selected model materials and sediments. A process is currently underway to reserve beam time at Argonne National Laboratory to support these experiments.

Experiments will be initiated to quantify carbon tetrachloride MRF magnitude and behavior in a range of artificially-aged sediments and as a function of carbon, clay and pore content of aged material, contact time, and concentration of $\mathrm{CCl}_{4}$ in the pore fluid (saturated conditions). As these experiments progress, efforts will be made to verify $\mathrm{CCl}_{4}$ behavior in artificially-aged sediment to $\mathrm{CCl}_{4}$ behavior in naturally-contaminated sediments and laboratory batch sorption/desorption experiments.

Information Access: Currently, no web page has been developed for this project, but additional information can be obtained by contacting the lead project PI, Robert G. Riley, at robert.riley@pnl.gov

Optional Additional Information: None

Optional Proprietary Information: None 